\title{
Spatial Patterns of Major Mortality Causes in Kuwait
}

\author{
M. M. AzIz*
}

\begin{abstract}
The paper examines the spatial patterning of the three major causes of mortality in Kuwait. Since the population of Kuwait is composed of two well-identified communities: Kuwaitis and non-Kuwaitis, the distribution of deaths will be affected by different social, economic and demographic characteristics of both groups.

Mortality rates are calculated per 100,000 of the total population according to the international classification of death causes. The major groups of mortality causes are: neoplasms, diseases of the circulatory system, and accidents and injuries, which are responsible for nearly two-thirds of the total deaths in Kuwait. Of all the causes, diseases of the circulatory system cause the highest rate of death. Accidents and injuries come second, followed by neoplasms.

Mortality rates from all causes are higher among Kuwaitis than among non-Kuwaitis. Rates are also higher in most cases among males of both communities than females. The highest figures of mortality, however, are those recorded in the Capital governorate including the township of Kuwait, and Jahra governorate, which is densely populated by foreign immigrants. Immigrants tend to suffer from accidents and injuries.
\end{abstract}

Key words: Kuwait, Kuwaiti, non-Kuwaiti, mortality rates, cardiovascular diseases, noeplasms, accidents, risks of death.

\section{INTRODUCTION}

Only a few population geographers have shown interest in mortality studies. Most of the work remains the concern of medical geography as it is regarded as an important sub-discipline of population geography. However, the main contribution of medical geographers has been aimed at the analysis of spatial differentiations of causespecific mortality and their relationships with social, economic, demographic and environmental conditions. 1) Since every disease shows spatial variations, analysis of the relationships between diseases and various conditions may provide an explanation to mortality causes and distribution. ${ }^{2)}$

This paper is being prepared esentially to reveal the spatial patterns of major causes of disease in Kuwait. It tries to identify and recognise the spatial distribution of diseases in administrative units of the country. Analysis of various causes can help to determine different variables exerting influence on distribution patterns. Such factors, however, will not be dealt with in this study, since it is more concerned with the spatial aspects of disease. The population of Kuwait is composed of almost totally different communities: Kuwaitis and non-Kuwaitis. ${ }^{3)}$ Spatial variations of disease will undoubtedly reflect the many different characteristics of both population groups and identify the causal relationships correspondingly.

Mortality rates are calculated per 100,000 of total population as in the following table. The seventeen major groups of death causes identified by the international classification are adopted and regrouped into three principal groups for the purpose of this study. ${ }^{4)}$ These are: neoplasms, diseases of the circulatory system, and accidents and injuries, which are responsible for nearly two-thirds of total deaths in Kuwait.

The study is based primarily on vital health and population data issued by the Ministries of Health and Planning in Kuwait, in addition to international sources. Basic data on death causes

*Department of Geography, University of Kuwait, Kuwait. 


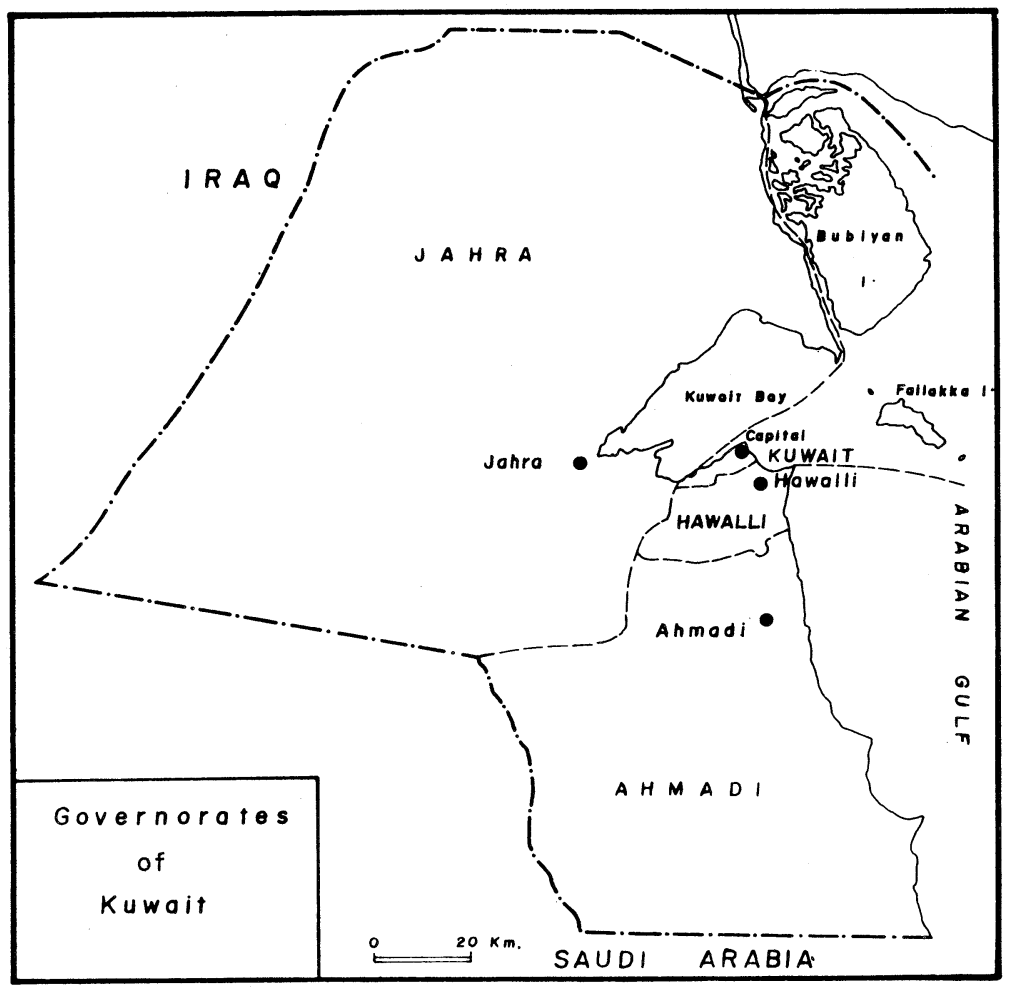

Figure 1. Governorates of Kuwait

Table 1 Mortality Rates in Kuwait by Major Causes of Death, Governorate, Nationality, and Sex, 1985 (Deaths per 100,000 persons in specified governorate)

\begin{tabular}{|c|c|c|c|c|c|c|c|c|c|c|c|c|c|c|c|c|}
\hline \multirow{3}{*}{$\begin{array}{c}\text { Cause of } \\
\text { Death }\end{array}$} & \multirow{3}{*}{$\begin{array}{l}\text { Nation- } \\
\text { ality }\end{array}$} & \multicolumn{12}{|c|}{ Governorate } & \multirow{2}{*}{\multicolumn{3}{|c|}{ Total }} \\
\hline & & \multicolumn{3}{|c|}{ Capital } & \multicolumn{3}{|c|}{ Hawalli } & \multicolumn{3}{|c|}{ Ahmadi } & \multicolumn{3}{|c|}{ Jahra } & & & \\
\hline & & M & $\mathbf{F}$ & $\mathrm{T}$ & $\mathbf{M}$ & $\mathrm{F}$ & $\mathrm{T}$ & M & $\mathrm{F}$ & $\mathrm{T}$ & $\mathbf{M}$ & $\mathrm{F}$ & $\mathrm{T}$ & $\mathbf{M}$ & $\mathrm{F}$ & $\mathrm{T}$ \\
\hline \multirow[t]{3}{*}{ Neoplasms } & $\mathrm{K}$ & 87.6 & 64.8 & 76.0 & 52.7 & 31.6 & 42.1 & 35.4 & 20.2 & 27.7 & 43.2 & 33.5 & & 55.0 & 84.2 & 44.5 \\
\hline & N.K & 26.7 & 18.1 & 23.3 & 20.2 & 20.0 & 20.1 & 12.6 & 13.0 & 12.7 & 30.1 & 17. & 25 & 21 & 20.3 & 21.1 \\
\hline & $\mathrm{T}$ & 43.4 & 40.6 & 42.3 & 28.0 & 23.7 & 26.2 & 22.1 & 17.2 & 20.0 & 39.4 & 30.7 & 35.4 & 33.2 & 26.7 & 30.4 \\
\hline \multirow{3}{*}{$\begin{array}{l}\text { Diseases of } \\
\text { Circulatory } \\
\text { System }\end{array}$} & $\mathrm{K}$ & 235.7 & 152.4 & 193.3 & 110.0 & 105.5 & 107.8 & & 59.1 & 73.7 & & & & & 90.2 & 108.0 \\
\hline & N.K & 98.6 & 33.1 & 78.3 & 67.0 & 37.2 & 54.8 & 68.7 & 35.3 & 57.2 & 71.7 & 39 & 60 & 77 & 37.7 & 62.0 \\
\hline & $\mathrm{T}$ & 137.9 & 90.6 & 119.8 & 77.4 & 58.9 & 69.4 & 77.0 & 49.1 & 65.2 & 86.8 & 60.7 & 74.6 & 94.2 & 62.2 & 80.4 \\
\hline \multirow{3}{*}{$\begin{array}{l}\text { Accidents } \\
\text { and } \\
\text { Injuries }\end{array}$} & K & 97.7 & 16.2 & 56.2 & 50.4 & 14.6 & & & & & & & & & 21.3 & 56.0 \\
\hline & N.K & 60.8 & 21.1 & 48.5 & 32.3 & 10.7 & 23.5 & 69.7 & 18.6 & 52.2 & 64.8 & 17.5 & 48.5 & 51.4 & 14.9 & 37.4 \\
\hline & $\mathrm{T}$ & 71.3 & 18.7 & 51.3 & 36.6 & 12.0 & 26.0 & 78.6 & 18.0 & 53.1 & 76.8 & 16.9 & 49.0 & 65.2 & 17.8 & 44.6 \\
\hline \multirow{3}{*}{$\begin{array}{l}\text { Total } \\
\text { (incl. others) }\end{array}$} & $\mathrm{K}$ & 626.4 & 418.2 & 520.3 & 402.9 & 312.0 & 357.3 & 403.1 & 247.3 & 324.7 & 432.5 & 303.5 & 367.8 & 480.0 & 321.0 & 400.0 \\
\hline & N.K & 244.5 & 153.6 & 216.4 & 186.0 & 135.2 & 165.3 & 225.4 & 161.5 & 216.5 & 270.6 & 201.8 & 246.9 & 222.5 & 152.0 & 195.5 \\
\hline & $\mathrm{T}$ & 353.9 & 281.0 & 326.0 & 238.3 & 191.2 & 218.0 & 299.8 & 211.3 & 262.6 & 385.8 & 285.7 & 339.2 & 313.0 & 231.0 & 277.7 \\
\hline
\end{tabular}

Basic Data from:

a) State of Kuwait, Ministry of Planning, Central Directorate of Statistics (1981): Bulletin of Vital Statistics: Births and Deaths 1980, Kuwait, pp. $110-124$, Tables $38 \mathrm{a}, \mathrm{b}$ and $\mathrm{c}$.

b) (1987), Bulletin of Vital Statistics: Births and Deaths 1985, Kuwait, Table 2.

c) (1986): General Census of Population 1985, Vol. I, Kuwait, p. 6, Table 2.

$\mathrm{M}=$ male, $\mathrm{F}=$ female, $\mathrm{T}=$ total 
have only been recently compiled on the basis of administrative units. ${ }^{5)}$ Only in the census year of 1985 have such data become available, and they will be used in this paper. $\left.{ }^{6}\right)$

It may be useful to mention the following general aspects before discussing the three major causes:

1. Diseases of the circulatory system acquire the highest mortality rates of the two remaining groups at both national and regional levels. Next comes the 'accidents and injuries' group, and finally the neoplasms.

2. Mortality rates for almost all causes of death are twice to three times higher among the $\mathrm{Ku}$ waitis than the non-Kuwaitis. This can be attributed mainly to the fact that the majority of immigrants or non-Kuwaitis is composed of adults (15 59), and also to differing social and economic characteristics of both communities, with particular reference to such parameters as following: different languages, cultures, traditions, educational standards, occupational structures, housing conditions, and average earnings.

3. Age composition of the Kuwaitis and non-
Kuwaitis differs to a great extent. Young people less than 15 years of age comprise about half of the total Kuwaiti population. Meanwhile the same age group comprises only about $29 \%$ of the non-Kuwaitis. ${ }^{7}$ In addition, adults comprise less than half of the Kuwait community, compared with nearly $70 \%$ of the non-Kuwaitis.

The same can be said about sex composition, where males comprise nearly $50 \%$ of both age groups for Kuwaitis, but among the non-Kuwaiti population they represent only a quarter of the under 15 age group, and three-quarters of the adult group. ${ }^{8)}$ Such differences can be seen in all parts of the country.

4. Because of the peculiar age and sex composition of the non-Kuwaitis, it is clear, generally, that female mortality rates for many causes exceed those of males, whereas among the Kuwaitis the opposite is true.

5. Since environmental conditions are almost similar in all parts of the country, they are not expected to have different areal impacts on disease causation. ${ }^{9)}$

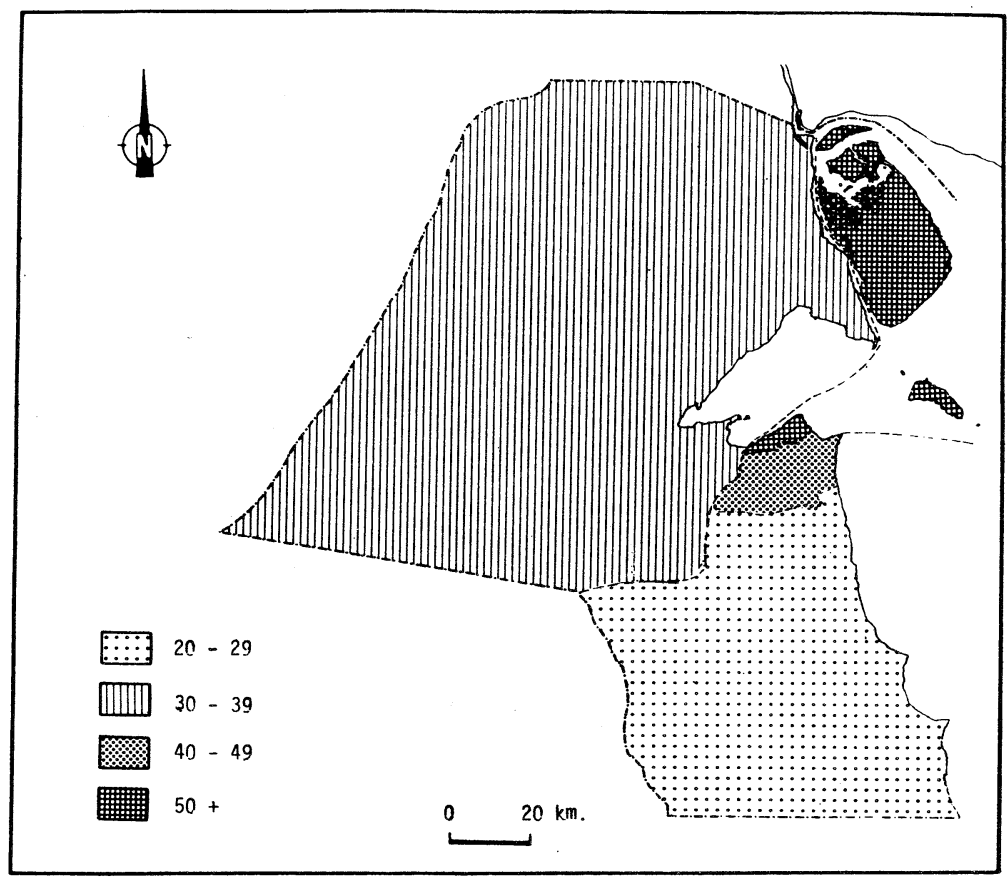

Figure 2. Mortality Rates for Neoplasms among Kuwaitis Per 100,000 persons 


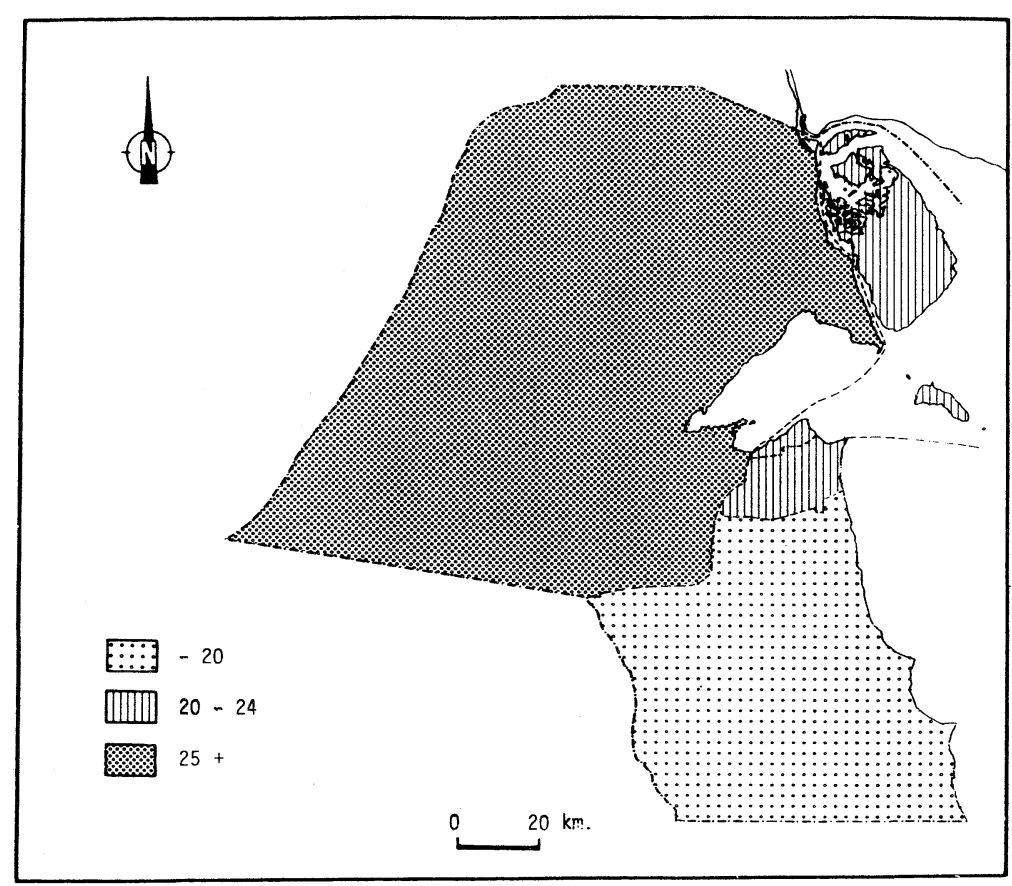

Figure 3. Mortality Rates of Neoplasms among Non-Kuwaitis Per 100,000 persons

\section{NEOPLASMS ${ }^{10)}$}

Death records show that this group is the third most important cause of death among the seventeen groups after heart diseases and accidents. This means that these diseases cause eleven out of every hundred deaths among the country's total population.

Figures for the past fifteen years do not show a significant change in the threat of these diseases to health in Kuwait, despite the slight increase and decrease among the Kuwaitis and nonKuwaitis respectively, and their position in the list of death causes. ${ }^{11)}$

The rates of mortality in 1985 at governorate level differ clearly from those for total population. Death rates in two governorates outnumber the national rates, while those in the other two are lower (Figs. 2 and 3). The highest figures can be seen in the Capital governorate, where they exceed the national figures by more than ten deaths. Moreover, death rates among Kuwaitis exceed those for immigrants by three times. ${ }^{12)}$

The risk of death from such diseases is also higher among males than females of both population groups. Population age and sex structure in addition to other factors may explain such differences. It seems that almost all types of neoplasms have been involved in deaths in Kuwait. Nevertheless more than $27 \%$ of them are caused by those of digestive organs. The Kuwaitis and the males of both groups are the major victims of these diseases, where deaths constitute $63 \%$ and about $80 \%$ of total deaths respectively. Deaths from such diseases in the Capital governorate however, comprise only about $15 \%$ of total deaths in all the governorates of Kuwait.

Malignant neoplasms of lymphatic and haematopoietic organs are the second and third most important causes of death in this governorate. They each are responsible for more than $30 \%$ of total deaths. More than three-quarters of the victims are Kuwaitis and female deaths comprise about two-thirds of total losses. These two causes of death in the Capital governorate account for more than $12 \%$ of their total deaths in the country.

Mortality rates in Hawalli governorate are much lower than those in the previous gover- 
norate and in Kuwait as a whole. Figures for its Kuwaiti inhabitants are almost twice those for non-Kuwaitis. Mortality levels for both population groups and sexes are the nearest among the governorates to those for the total population in the country. ${ }^{13)}$

Distribution of deaths on sub-causes shows that neoplasm of digestive organs is once more considered the major risk. It is responsible for the death of one person in every four that die in this governorate. For the first time, the majority of the victims (55\%) are non-Kuwaitis. This may be due to the fact that Hawalli has the oldest concentration of immigrants in Kuwait and they all enjoy similar living conditions compared with other governorates. Besides, about twothirds of the victims are men, and deaths from this disease in Hawalli comprise about half of its total deaths in the country.

The second most important cause is lymphatic neoplasm, which claims one in every five deaths caused by all the neoplasms. Two-thirds of the total deaths are among non-Kuwaitis too, while about $70 \%$ of them are males. It seems that this neoplasm represents a major threat, for it claims about $56 \%$ of all deaths in Kuwait. Neoplasms of both respiratory and genito-urinary organs represent almost equally the third most serious danger. The share of each cause is about $15 \%$ of total deaths and more than half of them are non-Kuwaitis. Male victims constitute more than $80 \%$ of respiratory deaths and about $60 \%$ of genito-urinary deaths. Deaths attributed to these two causes in this governorate account for more than $45 \%$ of their total deaths in the country.

Records show that the remaining daths are distributed among other causes, particularly neoplasms of unspecified sites and those of bone, skin and breast. Each of these two causes is responsible for about $45 \%$ of its total deaths.

The lowest mortality rates for neoplasms in Kuwait are those recorded in Ahmadi governorate, whether for its total population, or for both sexes. They are not more than two-thirds of those for the whole country. But like other governorates they are higher among Kuwaitis than among non-Kuwaitis, and among the lat- ter group the rates are similar for both sexes. ${ }^{14)}$ Neoplasms of digestive organs prove again to be the prime cause of death here as in other places, where about $30 \%$ of total deaths in this governorate are due to this cause. Kuwaitis comprise about two-thirds of all deaths due to this disease, while males of both communities comprise about $55 \%$ of them. Nevertheless, this governorate has only a $15 \%$ share of the total mortality from this cause.

Neoplasms of the respiratory organs is the second largest cause of death with a figure of $21 \%$. nearly two-thirds of total deaths are among Kuwaitis, and almost all recorded incidents are among males.

Ahmadi's contribution to total deaths in the country is small, with only a $16 \%$ share. Remaining death cases in Ahmadi are caused by neoplasm of the genito-urinary organs and those of bone, skin and breast.

The second highest death figures in Kuwait are those recorded in Jahra. They are clearly higher than those for total population, but lower among its Kuwaiti citizens than among all Kuwaitis in the state. Death rates among immigrants on the other hand, are the highest, whether compaed with total immigrant deaths in the country or those in other governorates. ${ }^{15}$

Neoplasm of digestive organs comes at the top of the list of causes once again with a share of more than $24 \%$ of all death causes. More than $82 \%$ of deaths caused by this neoplasm are Kuwaiti and two-thirds of the total deaths from it are males. In spite of this Jahra has less than a $20 \%$ share of the total number of deaths from this disease in the country.

The second highest number of deaths is caused by neoplasms of the lymphatic and genitourinary organs with a figure of $19 \%$. Neoplasms of the lymphatic organs in Jahra cause $24 \%$ of the total deaths from this disease in the country, while neoplasms of the genito-urinary organs in Jahra cause $20 \%$ of the total deaths from it in the country.

Other causes are only of little significance. According to death victims they have almost the same impact here as in previous governorates. 


\section{DISEASES OF THE CIRCULATORY SYSTEM ${ }^{16)}$}

This group of diseases represents the major risk to health in Kuwait. Its role has also been increasing with the passage of time. In 1970 it was the fourth most important cause according to the total number of death causes. This means that about $14 \%$ of total deaths were due to cardiovascular diseases. After only 5 years in 1975 this group came at the top of the death cause list and claimed more than $18 \%$ of all deaths in the country. ${ }^{17)}$ It continued to be the leading health threat in 1980, and with an enormous increase. It was now responsible for the deaths of three out of each ten victims of the two communities in Kuwait.

The situation is almost unchanged in 1985, with a slight increase of mortality among the Kuwaitis. The number of deaths among males during the above period was higher than among females.

The number of deaths caused by heart disease in Kuwait in 1985 almost equals the number caused by infectious diseases, neoplasms and accidents collectively.

Regional patterns show uneven distribution of mortality. Rates in all governorates but one are lower than the national average (Figs. 4 and 5). The highest figures are those recorded in the Capital governorate, where about four deaths of every 10 are caused by heart disease. The same is true for the male population, as figures for females are less than half those of males.

The impact of various sub-causes of this group varies greatly. In this governorate about $57 \%$ of total deaths are due to ischaemic heart diseases. Both Kuwaitis and immigrants are almost equally subject to these risks, but most deaths $(82 \%)$ occur among males.

Another $19 \%$ of total deaths are due to hypertensive diseases. Two-thirds of them are Kuwaitis, but unlike ischaemic heart diseases, more than $60 \%$ of the victims are females. However, deaths by such diseases constitute only about $14 \%$ of all cases in Kuwait.

Although the cerebrovascular diseases came third as a cause of death, their share of total mortality in the governorate is only about $10 \%$.

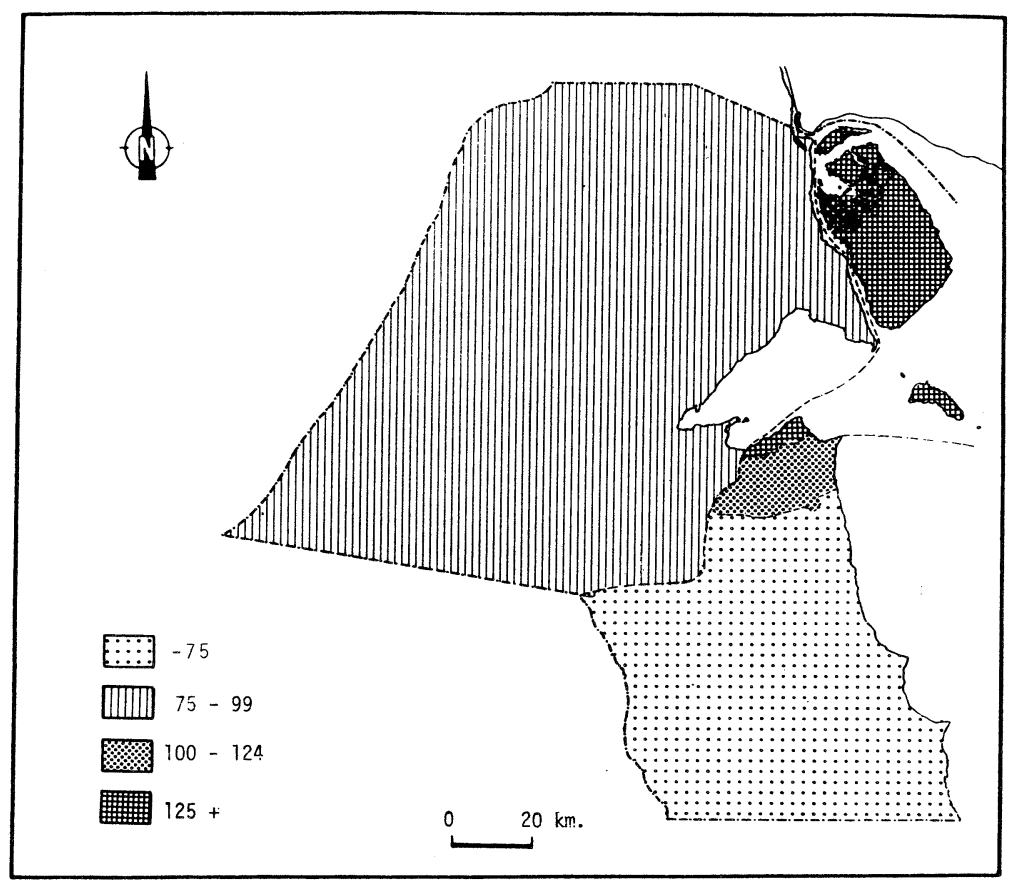

Figure 4. Mortality Rates for Circulatory System Diseases among Kuwaitis Per 100,000 persons 


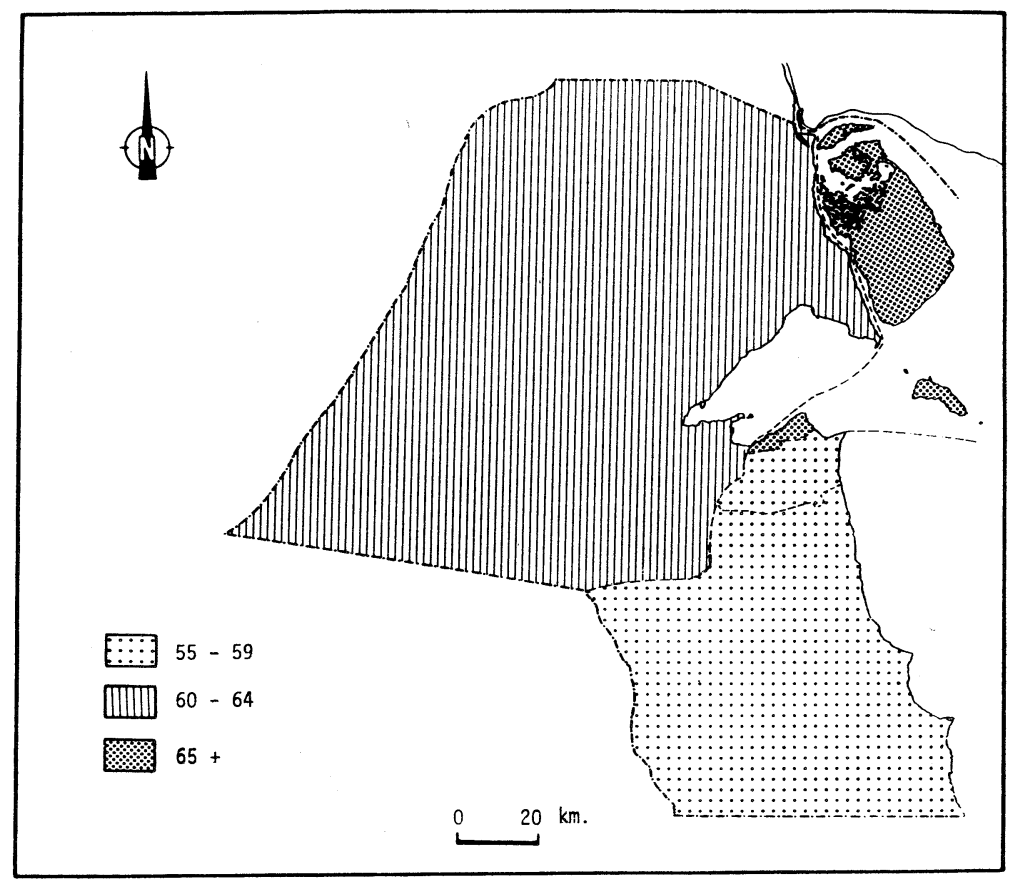

Figure 5. Mortality Rates for Circulatory System Diseases among NonKuwaitis

Per 100,000 persons

Kuwaitis and males prove to be the most vulnerable sections of the population.

The remaining small numbers of deaths are due to other causes of minor importance such as those of pulmonary circulation and other unspecified diseases of the circulatory system.

The dangers of heart disease seem to be lesser in the governorate of Hawalli. Only three out of every 10 deaths in 1985 in Hawalli were due to heart disease. These deaths were only about $10 \%$ of heart disease deaths in the country as a whole. Non-Kuwaitis, unlike in previous governorates, constitute aobut $57 \%$ of the victims. Male mortality constitutes about two-thirds of them.

About half of the deaths are the victims of ischaemic heart diseases. Two-thirds of them are non-Kuwaitis, and three quarters of deaths are males. The seriousnes of the diseases is explained by its high contribution to the total mortality of the governorate, which exceeds $37 \%$.

Hypertension is the second cause, which claims another $23 \%$, over half this figure being recorded among the immigrant settlers. Here again, as in the Capital governorate, females are the main target of this illness. But unlike the first cause it constitutes more than $54 \%$ of all deaths in the country.

Cerebrovascular disease is the third main cause, accounting for $13 \%$ of all deaths. The rate of deaths is almost equal between the Kuwaitis and the non-Kuwaitis, and also between the sexes. In spite of this, however, half of the total deaths from this disease in the country occur in Hawalli.

The remaining deaths in this governorate are caused by other diseases of the circulatory system, especially pulmonary and other unspecified diseases.

It seems that the lowest death figures are in Ahmadi governorate. This is clear from the fact that only a quarter of the total deaths in this governorate are caused by heart disease. $55 \%$ of these deaths are Kuwaitis, and only less than one-third of the victims are female.

The ischaemic group of diseases is also the leading cause of death here. It causes half of the total circulatory system deaths. Non-Kuwaitis comprise about $45 \%$ of these deaths. Female mortality from this disease is four times higher than that of males in Ahmadi. However, deaths 
from ischaemic diseases here amount to only $15 \%$ of the country's total number of deaths from circulatory system ailments.

The second biggest cause in this group is hypertension with a figure of $19 \%$. Of these deaths, three-quarters are Kuwaitis. Female mortality is unusually lower than that for males here. Deaths from hypertension in Ahmadi account for only $13 \%$ of the total deaths from it in the country.

Cerebrovascular diseases are only of minor importance here, as are other unspecified causes of death.

Finally, Jahra governorate had the second highest mortality rates from heart diseases in 1985. They caused two out of every ten deaths in the governorate. For every non-Kuwaiti that died, four Kuwaitis were victims, and for every four female deaths, there were six males.

Of the sub-causes, ischaemic disease seems to be the major one. They were responsible for about $35 \%$ deaths. $80 \%$ of them are Kuwaitis and $70 \%$ are male. Jahra's contribution to the total number of deaths from ischaemic diseases in the country is the lowest, with a figure of only $11 \%$.
Hypertensive and cerebrovascular diseases are the second biggest sub-cause with a joint figure of $40 \% .80 \%$ of deaths from these causes are Kuwaitis, and for every four female deaths, there are six male.

Less important causes of death in this governorate are the pulmonary and other circulatory system diseases.

\section{ACCIDENTS AND INJURIES ${ }^{18)}$}

According to death records, this group has been regarded as one of the leading causes of death in Kuwait for some time. In 1970 nearly $20 \%$ of all deaths in Kuwait were caused by accidents. This figure rose to about $30 \%$ in 1975 . In 1980 it became the second major cause of death in Kuwait after heart diseases. ${ }^{19)}$ Although the situation remained almost unchanged in 1985, there has been a slight increase in death tolls. The mortality rates were clearly much higher among the Kuwaitis and the males of both population segments in 1985. But the absolute figures show that non-Kuwaitis are the biggest sufferers, because of the wide range of

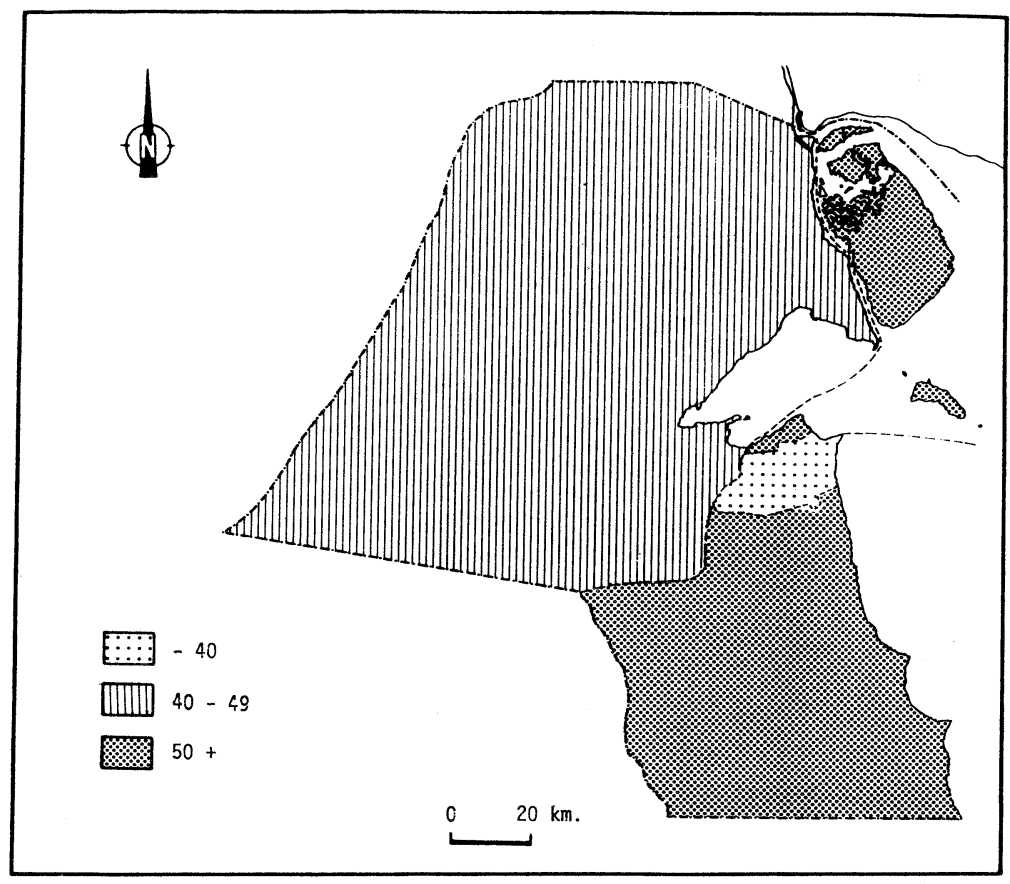

Figure 6. Mortality Rates for Accidents and Injuries among Kuwaitis Per 100,000 persons 


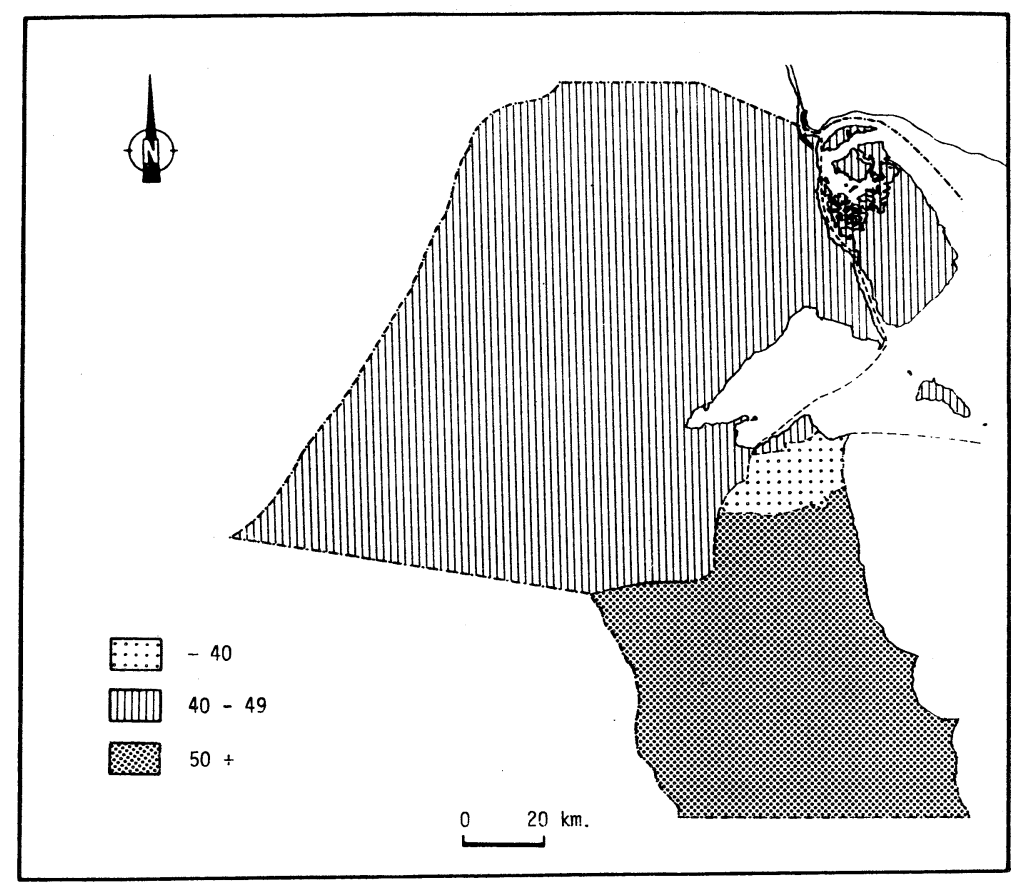

Figure 7. Mortality Rates for Accidents and Injuries among Non-Kuwaitis Per 100,000 persons

risks they expose themselves to in their search for better earnings (Figs. 6 and 7).

Another reason for the major role of accidents in the death toll is the large number of privately owned cars, which are the most important means of transport in Kuwait. Public transport does not contribute much to the death toll. The risks of death by accident are biggest in places where old settlements of both Kuwaitis and immigrants are located.

In the Capital about $16 \%$ of total deaths are due to accidents. Nearly two-thirds of the victims are immigrants, and for every nine males that die through accidents, there is only one female death.

Of the 10 sub-causes of accidents, transport accidents are the leading cause of death. Half of the total accident deaths in the governorate are caused by them. For every three Kuwaitis that die in accidents, seven non-Kuwaitis die. On the other hand, it seems that the Capital's contribution to the total number of road accidents in Kuwait is small, with a figure of only $8 \%$. The remaining proportion of deaths is attributed to other types of accidents such as homicide, in- juries inflicted by other persons and accidental falls.

In Hawalli $70 \%$ of accident victims are from the immigrant community. For every eight male deaths there are only two female deaths.

Road accidents are the biggest cause of death in this governorate. $60 \%$ of accident deaths are due to road accidents. The number of nonKuwaiti victims is twice that of the Kuwaitis, and male deaths outnumber female deaths by four to one. Unlike the Capital, this governorate contributes $30 \%$ to the number of road accident deaths in Kuwait. Other kinds of accidents play a secondary role, but the most important are accidents of fire and flame, misadventure during medical care, accidental falls, and other unspecified accidents.

Unlike in Hawalli, where the lowest mortality rates are recorded, those in Ahmadi are the highest. $20 \%$ of all deaths here are caused by accidents. Ahmadi's share of total accident deaths is only two-thirds that of Hawalli. Another difference between the two is that the risks of accidents are almost equally divided between the two distinct communities. In spite of this, males 
remain the principal target, and about nine of them die for every one female.

Transport accidents are again the major cause of death, but to a more serious degree here than in former governorates. Six out of every 10 deaths due to accidents are attributed to road accidents. Both sections of population are exposed equally to the dangers of traffic accidents. The male/female ratio of 9 to 1 confirms the high risks that the people here are facing. This is probably because Ahmadi is the governorate where most of the industrial and agricultural activities, and the largest current housing schemes are located. It also has common borders with Saudi Arabia, where there are many more oil installations and work opportunities. Therefore, large numbers of people move everyday on its roads, which can be considered the busiest in the country.

Later effects, which can be clearly related to road accidents, are the second biggest cause of death. They cause two of every 10 accident deaths, and almost all victims are male. The remaining small proportion of deaths are due to other accidents, particularly those of fall and fire.

Mortality figures in Jahra seem to be the second lowest of all the governorates. Accidents cause less than one-fifth of all deaths in this governorate. However, Kuwaiti and male victims outnumber non-Kuwaiti and female victims by four to one respectively. The high incidence of death here is due to circumstances similar to Ahmadi governorate.

Jahra occupies the northernmost part of the country close to the Iraqi and Saudi Arabian borders. Many of its residents usually travel to the nearby Kuwait city in the Capital governorate, where the largest business district is located.

It is not surprising, therefore, that transport accidents claim about two-thirds of total deaths, which is a higher figure than for Ahmadi governorate. For every seven Kuwaitis that die in road accidents here, there are less than three nonKuwaiti victims. When compared with Ahmadi's figures, this shows a significant increase. Males continue to be the main victims, as they comprise about $90 \%$ of total road deaths. This governorate contributes about $20 \%$ to the total num- ber of transport deaths in Kuwait, which is a little less than Ahmadi's contribution.

Later effects of accidents are the next biggest cause of death, and are of the same significance as in Ahmadi. Other accidents have only a negligible role in the total death figures.

\section{CONCLUSION}

This study tries to identify and recognize the spatial distribution of the three major causes of mortality in the four governorates of Kuwait. They are: diseases of the circulatory system, neoplasms, and accidents and injuries. Nearly twothirds of total deaths are due to these causes, but mortality rates for both Kuwaiti and nonKuwaiti communities are not similar.

Diseases of the circulatory system seem to be the major killer in the country. They are responsible for more than $30 \%$ of all deaths. Regional patterns show uneven distribution of mortality. The highest figures are recorded in the Capital governorate. In this governorate about twothirds of total deaths are due to ischaemic heart diseases. Both Kuwaitis and non-Kuwaitis are equally subject to these diseases and most deaths occur to males. The lowest death figures are in Ahmadi governorate where more than half of them are Kuwaitis, of whom two-thirds are females.

Mortality brought about by acidents and injuries has been regarded as one of the leading causes of death for some time. In 1985 it became the second major cause of death in Kuwait. Mortality rates are clearly much higher among the male Kuwaitis and non-Kuwaitis. But the absolute figures show that non-Kuwaitis are the biggest sufferers because of the wide range of risks they are exposed to in their search for better earnings. More than $60 \%$ of accident deaths are due to transport accidents only. Almost all victims are males, and two-thirds of the mortalities occur among those who are under 50 years of age.

The risks of death are biggest in the old settlements of both Kuwaitis and non-Kuwaitis. The highest mortality rates are recorded in Ahmadi, while the lowest in Hawalli.

Neoplasms represent the third major cause of death. They claim about $11 \%$ of total deaths in 
Kuwait. The highest figures can be seen in the Capital governorate, where death rates among Kuwaitis exceed those for immigrants by three times. Death risks are also higher among males than females of both communities. Although all types of neoplasms have been recorded, more than $27 \%$ of them are due to those of digestive organs. The males of both Kuwaitis and nonKuwaitis are the major victims.

(Received Aug. 9, 1988)

(Accepted Jan. 10, 1989)

\section{Notes and References}

1) Curson, P. H. (1986): "Mortality Patterns in the Modern World,' in PACiOnE, M. (ed.): Population Geography: Progress and Prospect, Croom Helm, London, p. 97.

2) PACione, M. H. (ed.) (1986): Medical Geography: Progress and Prospect, Croom Helm, London, p. 3.

3) Non-Kuwaitis are immigrants of different nationalities who reside in Kuwait for various reasons. In 1985 non-Kuwaitis composed about $60 \%$ of total population.

4) United Nations, World Health Organization (1977): Manual of International Statistical Classification of Diseases, Injuries and Causes of Death, Vol. 1, Geneva, pp. $101-144.259-282$, and 473-546.

5) The State of Kuwait is divided into the following major administrative units or governorates: the Capital, Hawalli, Ahmadi, and Jahra. They in turn are divided into about 80 smaller units of various sizes. These governorates also vary in area and population (Fig. 1).

6) A general census of population is usually carried out in Kuwait every five years. The first one took place in 1957, followed by six more in the years: 1961 , 1963, 1970, 1975, 1980, and 1985.

7) State of Kuwait, Ministry of Planning, Central Directorate of Statistics (1986): General Census of Population 1985, Vol. I, Kuwait, p. 6, Table 2.

8) Ibid., p. 6.

9) The State of Kuwait is located in the northwesternmost corner of the Arabian Gulf in southwest Asia, between $28.45-30.05^{\circ} \mathrm{N}$ and $46.30-48.30^{\circ} \mathrm{E}$. It covers an area of nearly 18,000 $\mathrm{km}^{2}$ with a population of two milions. As a rule, Kuwait is an arid hot country. Modern Kuwait has been witnessing spectacular economic, social, urban and demographic changes, since the beginning of the oil era in 1950.

10) This group includes the following sub-causes:

1. Malignant neoplasm of lip, oral cavity, and pharynx

2. M. neoplasm of digestive organs and peritoneum.
3. M. neoplasm of respiratory and intrathoracic organs.

4. M. neoplasm of bone, connective tissue, skin and breast.

5. M. neoplasm of genito-urinary organs.

6. M. neoplasm of other and unspecified sites.

7. M. neoplasm of lymphatic and haematopoietic tissue.

8. Benign neoplasm.

9. Carcinoma in situ.

10. Other and unspecified neoplasm.

11) a. AzIz, M. M. (1987): Cause-Specific Mortality in Kuwait: A Study in Medical Geography, Vol. I, 1970-75, University of Kuwait, That AlSalasil, Kuwait, p. 65 (in Arabic).

b. AzIz, M. M. (1987): Cause-Specific Mortality in Kuwait: A Study in Medical Geography, Vol. II, 1980-85, University of Kuwait, Al-Qabas Press, Kuwait, p. 211 (in Arabic).

12) Although this is the location of the capital city of the state and the oldest inhabited area of the country, Kuwaitis represent only about $36 \%$ of the total population here. Source: op. cit. 7), p. 2, Table 1.

13) This governorate, in contrast to the Capital, represents the oldest residential area for non-Kuwaiti immigrants. Kuwaitis, therefore, are considered only a small minority or about $27 \%$ of the governorate's total population, ibid., p. 4, Table 1 .

14) Unlike previous governorates, Kuwaitis here constitute about half of its total population, ibid., p. 5, Table 1.

15) People from eastern and northern parts of the Arabian Peninsula have been attracted to the Jahra Oasis for a long time, and Kuwaiti citizens constitute more than $76 \%$ of the total population, ibid., p. 5 , Table 1.

16) This group includes the following sub-causes:

1. Rheumatic fever and rheumatic heart diseases.

2. Hypertensive diseases.

3. Ischaemic heart diseases.

4. Diseases of pulmonary circulation and other diseases.

5. Cerebrovascular diseases.

6. Other diseases of the circulatory system.

17) a. State of Kuwait, Ministry of Planning, Central Directorate of statistics (1979): Bulletin of $\mathrm{Vi}$ tal Statistics, Births and Deaths 1970-1978, Kuwait, pp. 47-55, Tables 23a, b and c.

b. AzIZ, M. M., op. cit., 11)-b, p. 122.

18) This group includes the following sub-causes:

1. Transport accidents.

2. Accidental poisoning.

3. Misadventures during medical care and abnormal reactions.

4. Accidental falls.

5. Accidental causes by fire and flames.

6. Other accidents including late effects.

7. Drugs and medicaments causing adverse effects.

8. Suicide and self-inflicted injury. 
9. Homicides and injuries purposely inflicted by other persons.

10. Other violence.

19) op. cit., (m) p. 141.

\section{Other References}

Abdul-Halim, R. E. (1985): "Some observations on cancer bladder in Saudi Arabia", Emirates Medical Journal, 3, $203-206$.

Al-Adnani, M. S. (1984) "Cancer in Southern Iraq", Journal of Kuwait Medical Association, 18, 81 - 87.

AzIz, M. M. (1986): "Natural Increase Differentials in Kuwait", Journal of the Gulf and Arabian Peninsula, University of Kuwait, No. 48, 15-51 (in Arabic).

BARretT, F. A. (1986): "Medical Geography: Concept and Definition"' in M. H. PACIONE (ed.), op. cit. (2), $1-34$.

BARTLEY, M. (1988): “Unemployment and Health: Selection of Causation - A False Antithesis Sociology of Health and Illness," A Journal of Medical Sociology, 10-1, 41-67.

BHARDWAJ, S. M. (1978): “Some Directions in Applied Medical Geography: Third World Perspective," in J. W. Frazier and B. J. Epstein (eds.), Applied Geography Conference, State University of New York, pp. $318-330$.

Brownies, A. A. (1972): "Modeling the Geographic Epidemiology of Infectious Hepatitis," in N. D. McGlashan (ed.), Medical Geography, Methuen and Co., London, pp. 279-300.

Clarke, J. I. (1984): Geography and Population: Approaches and Applications, Pergamon, London.

Cliff, A. D. and Haggett, P. (1986): “Disease Diffusion' in M. H. PACIONE (ed.), op. cit. (2), 84-125.

CUMPER, G. (1983): “Economic Development, Health Services and Health,"' in K. LEE and A. Mills (eds.), The Economics of Health in Developing Countries, Oxford University Press, pp. 23-42.

DinMAN, B. D. (1988): "Alumina-Related Pulmonary Disease', Journal of Occupational Medicine, 30-4, $328-335$.

EkMAN, P. (1986): "Prostate Cancer - To Treat or Not to Treat?", Emirates Medical Journal, 4-2, 90-94.

ELl-BushaRA, S. (1980): "The Distribution of Population and Medical Facilities in Saudi Arabia, Erdkunde, 34-3, 215-218.

Fox, D. J. (1972): “Patterns of Morbidity and Mortality in Mexico City", Geographical Review, LXII-2, $151-185$.

Fox, A. J. and Goldblat, P. O. (1982): Longitudinal Study: Socio-Demographic Mortality Differentials, HMSO, London.

French, G. E. and Hill, A. G. (1971): Kuwait, Urbanization and Medical Ecology. A Geomedical Study, Springer, Berlin.

Gerald, F. R. (1979): Applied Medical Geography, John Wiley and Sons, Washington.
Gilbert, A. and Gugier, J. (1982): Cities, Poverty and Development: Urbanization in the Third World, Oxford University Press, Oxford and N.Y.

GlicK, J. B. (1982): "The Spatial Organization of Cancer Mortality"'A.A.A.G., 72-4, 471-481.

Gray, M. (1979): Man Against Disease, Oxford University Press.

Gross, F., Piso, Z., Strasser, T. and Zanchetti, A. (1984): Management of Arterial Hypertension. W.H.O., Geneva.

Hellen, J. A. (1986): "Medical Geography and the Third World, in M. H. PACIONE (ed.), op. cit. (2), pp. $284-323$.

Howe, G. M. (1976): “Environmental Factors in Disease", in J. LENIHAN and W. FLETCHER (eds.) Health and Evironment, Blackie, London.

Howe, G. M. and Loraine, J. A. (eds.) (1974): Environmental Medicine, Heinemann Medical, London.

Howe, G. M. and PhILliPs, D. R. (1983): "Medical Geography in the United Kingdom, 1945-1982', in N. D. McGlashan and J. R. Blunden (eds.), Geographical Aspects of Health, Academic Press, London, pp. 33-52.

Huw, R. J. (1981): A Population Geography, Harper and Row, London.

James, G. D., Yee, L. S., Harshfield, G. A. and PiCKERING, T. G. (1986): "Sex Differences in Factors Affecting the Daily Variation of Blood Pressure", Social Science and Medicine, 26-10, 1019-1023.

KANNEL, W. B. and Thomas, J. T. (1986): Incidence, Prevalence and Mortality of Cardiovascular Diseases in the Heart, Arteries and Veins"' in J. W. HuRST (ed.), The Heart, McGraw-Hill Publishing Co., N.Y., pp. $557-565$.

KARVONEN, M. and MikHeEv, M. I. (eds.) (1986): Epidemiology of Occupational Health, W.H.O., Regional Publication, No. 20, Copenhagen.

KemP, I., Boyle, P., Smans, M. and Muir, C. (eds.) (1985): Atlas of Cancer in Scotland 1975 - 1980, Incidence and Epidemiological Perspective, W.H.O., IARC, Publications No. 72, Lyon.

Kvale, G. and Heuch, I. (1988): "Lactation and Cancer Risk: Is There a Relation Specific to Breast Cancer?" Journal of Epidemiology and Community Health, 42-1, 30-37.

MAYer, J. D. (1986): “Ecological Associative Analysis", in M. H. PACIONE (ed.), op. cit. (2), pp. 64-83.

McCrACKEN, K. W. (1981): Analysing Geographical Variations in Mortality: Age-Specific and Summary Measures,' Area: 13, 203-210.

MeAKE, M. S. (1977): "Medical Geography as Human Ecology: the Dimension of Population Movement,', Geographical Review, 67-4, 379-394.

Peter, J. (1988): “Dietary Factors in Benign Breast Disease," The Cancer Bulletin, The University of Texas, 40-1, 44-50.

PrIOR, P. (1988): "Long-term Cancer Risk in Alcoholism," Alcohol and Alcoholism, 23-2, 163-171. Pyle, G. F. (1979): Applied Medical Geography, John 
Wiley and Sons, Washington.

Pyle, G. F. (1976): “'Introduction: Foundations to Medical Geography," Economic Geography, 52-2, 95- 102 .

Rootman, I. and Moser, J. (1984): Guidelines for Investigating Alcohol Problems and Developing Appropriate Responses, W.H.O., Offset Publication No. 81, Geneva.

SuRESH, S. A. (1987): “A Comparative Study of Cancer in North-West India and Saudi Arabia,' The Second U.A.E. Cancer Conference, p. 76.

Troyer, H. (1986): "Review of Cancer Among Four Religious Sects: Evidence that Life-Styles are Distinctive Sets of Risk Factors,"' Social Science and Medicine, 26-10, $1007-1017$.

United Nations, World Health Organization (1962): Arterial Hypertension and Ischaemic Heart Disease: Preventive Aspects, Technical Report Series, No. 231,
Geneva.

(1978): Arterial Hypertension, Technical Report Serires, No. 628, Geneva.

(1985): Blood Pressure Studies in Children,

Technical Report Series, No. 715, Geneva. (1959): Hypertension and Coronary Heart Disease: Classification and Criteria for Epidemiological Studies, Technical Report Series, No. 168, Geneva. (1982): Prevention of Conorary Heart Disease,

Technical Report Series, No. 678, Geneva. (1983): Primary Prevention of Essential

Hypertension, Technical Report Series, No. 686, Geneva.

(1964): Rehabilitation of Patients with Cardiovascular Diseases, Technical Report Series, No. 270, Geneva.

(1962): Road Traffic Accidents: Epidemiology, Control and prevention, Geneva.

\title{
クウェートにおける主な死亡原因の地域パターン
}

\author{
M. M. ア ジ ズ*
}

本研究はクウェートに拈ける 3 大死亡原因を地域的に 考察したものである。クウェートの人口は, クウェート 人と非クウェート人の 2 つの明瞭に異なるコミュニティ から成り立って招り, 両グループの社会的, 経済的, 人 口学的性格は死亡の分布に大きく影響している。

死亡率は, 死因に関する国際的分類により10万人ごと に算定した。主な死因は腫瘍, 循環器系疾病, 事故傷害 の 3 つで, これらで全国の死亡の 3 分の 2 近くを占め
る。特に循環器系疾病による死亡率は高く, 次いで事故 傷害, 腫瘍の順である。

クウェート人の間の死亡率は非クウェート人のそれよ りも高い。また，両コミュニティとも，女子より男子の 方が死亡率が高い。地域的には，クウェート市を含む首 都地区とジャハラ地区で特に高い。移民は，事故傷害に かかりやすい。 